\title{
Psychogene niet-epileptische aanvallen: verschillen in semio- logie, maar ook in etiologie?
}

In deze rubriek wordt het fenomeen 'psychogene nietepileptische aanvallen' (PNEA) belicht vanuit twee verschillende perspectieven. Er is een bijdrage over een diagnostiek programma dat bedoeld is om snel tot een adequate diagnose te komen, omdat het vroeg stellen van de diagnose de kans op een gunstige prognose verhoogt. In een tweede bijdrage gaat het om de kenmerken van PNEA bij patiënten met een verstandelijke beperking. In beide bijdragen staat de etiologie van PNEA ter discussie.

Anne Marthe Meppelink en José Polet gaan er in hun bijdrage van uit dat PNEA valt onder de overkoepelende diagnose 'functionele neurologische stoornis' (FNS). De auteurs geven aan dat de diagnose 'functionele niet-epileptische aanvallen' meer recht doet aan de overlappende presentaties en gepostuleerde onderliggende mechanismen. Bovendien, zo zeggen zij, lijkt het onderscheid tussen functioneel en psychogeen kunstmatig en gebaseerd op semantiek (bijvoorbeeld een functionele dystonie of een niet-epileptische aanval met als uiting verkramping). Ook in de bijdrage van Haenen et al., die verslag doen van hun onderzoek naar de kenmerken van PNEA bij mensen met een verstandelijke beperking, wijzen de auteurs erop dat bij patiënten met een verstandelijke beperking de aanvallen zich veelal afspelen op gedragsmatig niveau. De vraag is in hoeverre PNEA en een FNS een gemeenschappelijk onderliggend framework hebben, met een vergelijkbare etiologie en met vergelijkbare biomarkers voor diagnostiek en behandeling en of dit framework ook verklarend zou kunnen zijn voor PNEA bij patiënten met een verstandelijke beperking.
In een recente publicatie in Brain van Sadnicka et al. (2020) werd een significant verschil gerapporteerd in drift rate voor patiënten met een functionele bewegingsstoornis en controles. Drift rate is een parameter in het diffusion model met behulp waarvan verschillende onderdelen van het reactie- en beslissingsproces tijdens cognitieve testen kan worden vastgelegd (Ratcliff, 20I4). Daarmee kunnen de snelheid en precisie waarmee sensorische informatie wordt verwerkt worden beoordeeld, die lager bleken te zijn bij patiënten met functionele bewegingsstoornissen in vergelijking met controles. De verklaring die hiervoor werd gegeven is het verschil in informatieverwerking, dat volgens de auteurs een algemeen kenmerk is van semiologisch verschillende functionele stoornissen en dus niet specifiek voor bewegingsstoornissen. Drift rate is daarmee een mogelijke ex-perimentele marker voor verschillende functionele stoornissen. Als PNEA en FNS een gemeenschappelijk onderliggend framework hebben, zou de drift rate mogelijk ook een marker voor PNEA kunnen zijn. Vervolgonderzoek zou moeten uitwijzen of dit daadwerkelijk geldt, met name ook voor patiënten met een verstandelijke beperking.

\section{Referenties}

Ratcliff R (2014) Measuring Psychometric Functions with the Diffusion Model. J Exp Psychol Hum Percept

Perform. 40(2): 870-888.

Sadnicka A, Daum C, Meppelink AM, Manohar S, Edwards M (2020). Reduced drift rate: a biomarker of impaired information processing in functional movement disorders. Brain 143; 674-683

\section{Lees het actuele overzicht van congressen over epilepsie.}

\section{Kijk voor meer informatie op www.epilepsieliga.nl.}

